\title{
OWNERSHIP, TECHNOLOGICAL CAPABILITIES AND EXPORTS OF GARMENT FIRMS IN MYANMAR
}

\author{
Rajah RASIAH, Myo Myo MYINT \\ Department of Development Studies, Faculty of Economics and Administration Building, \\ University of Malaya, 50603 Kuala Lumpur, Malaysia
}

Received 08 September 2011; accepted 14 April 2012

\begin{abstract}
This paper uses the evolutionary framework to examine the relationship between ownership, technological capabilities and export intensities using garment manufacturing in the Least Developed Country of Myanmar as an empirical case. The results show that foreign firms with production connected to global value chains enjoy higher export intensity than national firms even when controlled for age. Also, foreign firms with access to superior support from parent plants enjoy higher technology capability than national firms even after controlling for age. The Levene's two-tail ' $\mathrm{t}$ ' tests show that foreign firms also enjoyed higher human resource, process technology and adaptive capabilities than national firms. Foreign firms are also larger and pay higher wages than national firms. The results show that foreign firms' superior market access and technological capabilities can offer the potential for knowledge spillover to national firms provided the government stabilizes the political situation and strengthens the basic and high technology infrastructure in Myanmar. Unlike the Maquiladoras of Latin America, not only that a quarter of the inputs are sourced by garment firms from Myanmar, a handful of national firms have already acquired the export and technological capabilities to compete with foreign firms.
\end{abstract}

Keywords: ownership, exports, technological capabilities, Least Developed Country, Myanmar.

Reference to this paper should be made as follows: Rasiah, R.; Myint, M. M. 2013. Ownership, technological capabilities and exports of garment firms in Myanmar, Technological and Economic Development of Economy 19(Supplement 1): S22-S42.

JEL Classification: L6, O14, O31, O33.

\section{Introduction}

Myanmar is the second largest country in Southeast Asia after Indonesia, sharing borders with Bangladesh, India, China, Laos and Thailand. It is endowed with rich natural resources including minerals, precious stones, timber, oil and natural gas. When independence from

Corresponding author Rajah Rasiah

E-mail:rajah@um.edu.my 
British was granted in 1948, Myanmar experienced an instable economic regime for a decade followed by repressive isolationist policies. Export-orientation was introduced in the 1990s after the military government came to power. Along with the transition to a market economy, incentives were introduced to attract investment under the foreign direct investment (FDI) laws enacted in 1988. Labor-intensive garment manufacturing became an important recipient of foreign direct investment since. Further efforts at increasing the scope of private sector activity included: permission for the opening of private commercial banks, lifting of restrictions on trade, foreign equity, improvements in the legal and regulatory framework, physical infrastructure and the establishment of industrial zones after the promulgation of the Private Industrial Enterprise Law in 1990. These developments stimulated a massive expansion in garment manufacturing, which accounted for $48.6 \%$ of overall exports of Myanmar in 2000 (WTO 2012).

Least Developed Countries (LDCs) such as Myanmar also benefitted from preferential access to export markets following the termination of the Multi-Fiber Arrangement (MFA) that governed clothing trade at the end of 2004. Although the momentum of growth arising from such preferential treatment in the garment sector was hampered when the United States' subsequently imposed economic sanctions on Myanmar in 2003, garment exports has gradually risen again through rapid growth in exports to Japan, and through third countries. The European Union has also remained an important market.

Wages are no longer the only important pillar of competitiveness in garment manufacturing as other factors have begun to assume increasing prominence. Competitiveness in export markets cannot be maintained without at least adaptive changes to technology. In low end segments of garment manufacturing although competing firms may rely on easily absorbable technologies their capacity to compete requires the development of adaptive capabilities to continuously reduce costs, defects and delivery times, and raise quality (Rasiah 1994). While many studies have analyzed the determinants and inter-firm differences that contribute to performance differences between foreign and national firms, there has been little work examining the relationship between technological capabilities and export performance by ownership in low end industries in the LDCs. Because developed markets demand standardized quality, price and delivery times of low margin firms targeting such markets ought to show similar technological capabilities irrespective of ownership. However, with their stronger firm-specific assets foreign firms in LDCs can easily relocate capabilities from home to host sites and also operate on a large scale compared to national firms who will have to acquire or develop capabilities from scratch (Dunning 1995; Rasiah 2009; Narula, Dunning 2010).

Hence, this paper seeks to examine if foreign controlled garment firms in Myanmar enjoy higher export intensities and technological capabilities than national firms. Higher export and technological capabilities in foreign firms can offer national firms the potential of learning through demonstration effect and the hiring of experienced personnel from the former. The realization of such a potential by national firms in a LDC will depend on the capacity of the embedding institutions, which as Hirschman (1970) had noted, will rest considerably on the policies of the host-government. There currently exists a lacuna in the literature on the capacity of national firms to upgrade in the presence of foreign firms in LDCs. The rest of the paper is organized as follows. Section 1 discusses the development of garment manufacturing 
S24 R. Rasiah, M. M. Myint. Ownership, technological capabilities and exports of garment firms...

in Myanmar. Sections 1 and 2 present the theoretical guide, and the methodology and data respectively. Section 3 analyses statistically the significance of ownership in exports and technological capabilities. The paper finishes with the conclusions.

\section{Garment manufacturing}

Like several other LDCs, Myanmar began to receive strong inflows of FDI in garment manufacturing since the second half of the 1990s as efforts were underway to terminate the Multi-Fibre Agreement by 2004. The preferential access agreements with the United States and the European Union in particular drove export growth in the Myanmar garment sector, though low wages and set-up costs helped as well. Whether owned by foreign equity or national firms export-oriented garment firms largely specialized in cut, make, and pack (CMP) activities. Most foreign firms were multinational subsidiaries from Korea, Taiwan, Hong Kong and other Asian countries. Buyers abroad do everything but production, who undertake the marketing and links with the retail chains and design of clothes with detailed specifications, and in many cases procure and supply raw materials to the garment firms in Myanmar (Kudo 2005; Rasiah, Ofreneo 2009).

There were 25 national firms in Myanmar when the pioneering foreign firm from South Korea relocated in 1996, which was followed by firms from Taiwan and Hong Kong after 1997 (Myint 2011). The establishment of these firms not only motivated major buyers to take advantage of Myanmar's LDC quota but were also motivated by the growth of domestic firms engaged in export markets. With more buyers looking into Myanmar, national entrepreneurs were able to set up small, medium and even large operations to supply niche high volume and labour intensive markets. Also, a large proportion of foreign garment firms use national subcontractors in order to meet stiff deadlines. The number of firms engaged in the export sector rapidly increased to almost 300 firms in 1999.

The number of garment firms in Myanmar peaked at 400 in 2001, which included about 100 small national firms that focused on specialized subcontract orders (MGMA 2010). There were 75 foreign firms in 2001. The total employment in the garment industry was estimated at around 135,000 persons in 2001.

Under pressure for human rights abuse in the United States and Europe, garment manufacturing in Myanmar began to face serious problems from the early 1990s. Although the foreign firms survived through their international networks, local firms faced severe difficulties in securing orders, including bureaucratic red tape, a problematic multiple exchange rate and poor infrastructure. The final blow came in 2003 when the United States government imposed sanctions on Myanmar. As a result, around 55 foreign, 185 national firms shut down operations as export orders contracted leading to an estimated retrenchment of 70,000-80,000 workers in 2003-04 (Myint, Rasiah 2012). The number of foreign garment firms fell to 20 in 2004.

Myanmar's main garment export targets were the United States, European Union and East Asia before the US imposed economic sanctions in 2003. The United States more than doubled its imports from US\$185.7 million in 1999 to US\$403.5 million in 2000 (Myint 2011: Table 2.8). The United Kingdom is the second largest buyer followed by Germany. Fortunately for Myanmar the fall in exports to the United States has been somewhat offset by a rise in 
exports to Japan. Garment exports to Japan in dollar value terms increased threefold from 2003 to 2007 (Fig. 1). Exports to Japan accounted for 0.5\% of total garment exports in 1997 but this share rose to $4.3 \%$ in 2003 and $34.4 \%$ in 2007. Also, the number of firms registered with the Myanmar Garment Manufacturers Association (MGMA) grew slightly with foreign and national firms totalling 23 and 107 respectively in 2010 (Myint 2011).

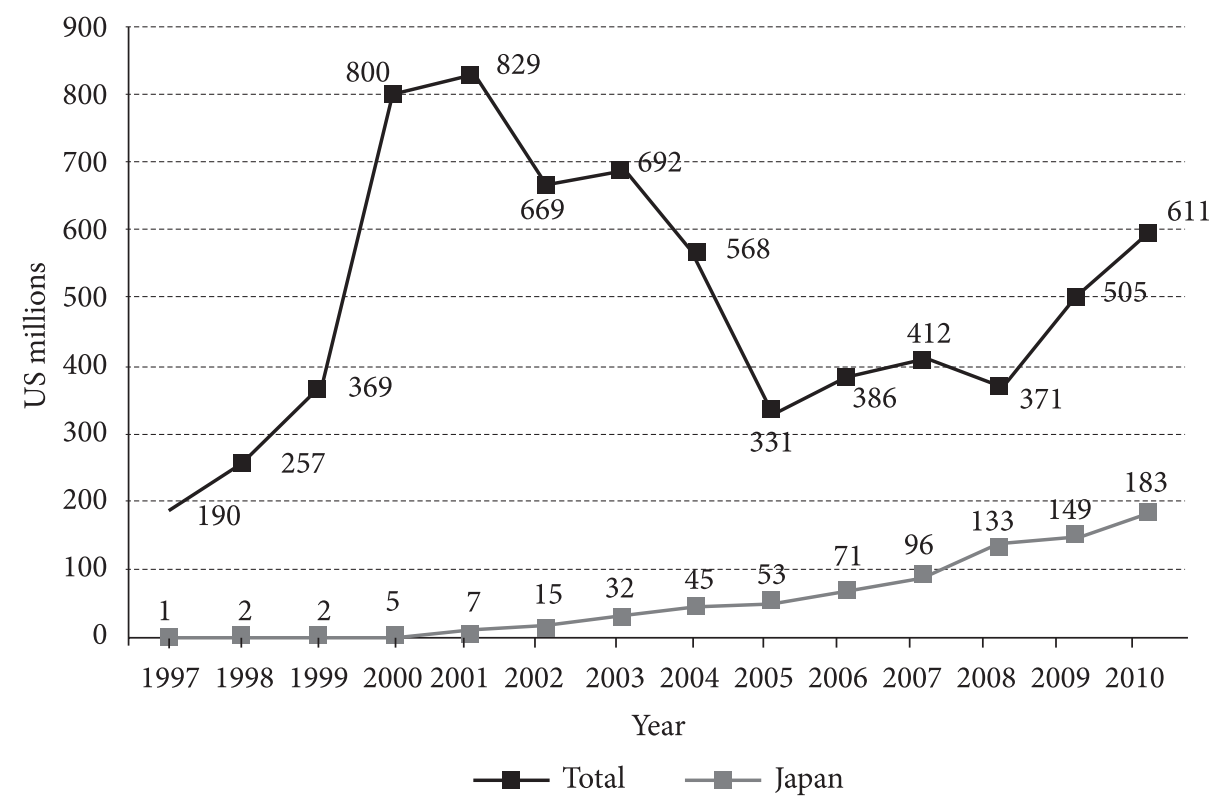

Fig 1. Garment exports, Myanmar 1997-2010

Myanmar is an interesting country for examining the role of foreign equity in the development of technological capabilities as it is a LDC starting at the bottom of the technology ladder, and has managed to break in and expand in a technology-using industry where the decomposition of production on the basis of the Babbage principle has enabled the relocation of low value added activities associated with CMP operations. It is important to investigate if the opportunity offered by such a link to global value chains is translated into export synergies and technological upgrading in Myanmar. Although this is a difficult proposition as CMP operations in several countries have enjoyed little technological upgrading, ${ }^{1}$ it is an opportunity for especially a country with large labor reserves such as Myanmar to use the opportunity to upgrade through the development of meso organizations in training, testing, logistics coordination as successfully undertaken by national firms in Korea, Taiwan, Hong Kong, India, China, Malaysia and Indonesia (Rasiah, Ofreneo 2009).

\footnotetext{
Barrientos (2008) produced evidence to show how several labor-contracting locations in the developing world only serve to reduce the bargaining position of workers and undermine the real application of codes of conducts by transnational firms.
} 
Also, unlike the moribund operations associated with Maquiladoras where in-bond processing and assembly of imported inputs for export are carried out in tariff and tax free locations without much value added recorded at host-sites (Fatemi 1990), Myint (2011) reported that garment firms in Myanmar sourced 25\% of their inputs domestically, which is higher than the commensurate percentage of 10-20 \% in Sri Lanka and 20\% in Vietnam in 2004. Hence, the industry may have the resource endowments for it to be rooted in Myanmar with the right policies.

\section{Concept and theory}

As presented by Gereffi (1994) and Sturgeon and Gereffi (2009), brand holders and giant retailers in the developed countries largely determine the location and terms of garment production, while manufacturers are forced to compete for orders by constantly lowering the cost of labor and increasing the speed of production (turnaround time) often with considerable flexibility to absorb quick changes in customer taste (Bailey et al. 1993; Singleton 1997). In such segments of garment production differences in performance between countries and between firms within the country are influenced by differences in skills, wages, scale and technology. With the increasing demands made on the workforce in terms of multiple higher-order skills, firm-level training is important to complement formal education. ${ }^{2}$ Because export-oriented firms in low cost and margin, and high volume production require scale and operative flexibility, firms show fairly strong technological capabilities to compete in external markets (Rasiah 1994; Lall 1999). Technological capabilities is the main concept of the paper, and the three key relationships reviewed from past works are between one, ownership and export-intensity; two, ownership and technological capabilities; and three, export-intensity and technological capabilities. We also examine in this section the influence of the control variables of age, wages and size on the explanatory variables.

\subsection{Technological capabilities}

Marx (1957) and Schumpeter (1934) had already demonstrated the significance of technology and innovation in driving growth. Schumpeter (1934) referred to 'creative destruction' to technical change that arises from innovations that rely on existing stocks of knowledge in sectors facing low barriers to innovation. Firms either marry different types of knowledge or adapt existing stocks of knowledge to generate new processes, products and organizational structures that help lower costs and delivery times and increase flexibility and quality. Neo-Schumpeterians referred to 'creative accumulation' activities to knowledge paths that connect and lead to the opening up of newer paths by large firms in sectors characterized by high barriers to entry (Malerba 2005). Such path-dependent breakthroughs are important to generate new cycles of innovation. ${ }^{3}$ Evolutionary economics models added further

2 Basic schooling and high literacy rates may be sufficient to absorb simple technologies.

3 Although innovation capabilities are a dynamic concept its meaning is very broad as it encompasses the creation of something new in the interest of individuals, markets, governments and societies, including ideas and services rather than just products, processes and technologies (Wikipedia 2012). It is because of this, the narrower concept of technological capabilities is preferred here. 
emphasis to the understanding of technology by advancing the concept of systems of innovation and its composition as a constellation of economic agents (firms and institutions) and the relationships between them (Freeman 1987, 1989; Lundvall 1992; Nelson, Winter 1982). Nelson (2008) showed that the functioning and change in each system is uniquely different, non-linear and heterogeneous in nature. However, because the garment industry is a technology user and is dominated by labor-intensive production methods, the focus in the paper is on technological capabilities that at most will come near Mark I activities. The operations in an underdeveloped LDC such as Myanmar are expected to be well behind the technological frontier.

In discussing capabilities, it is important to address the dynamic management capabilities advanced by Teece (2009). Teece (2009) articulated the concept of dynamic capabilities by referring to skills, processes, routines, organizational structures, and disciplines that enable firms to build, employ, and orchestrate intangible assets relevant to satisfying customer needs, and which cannot be readily replicated by competitors. Using this logic one can see the need for firms to strengthen their managerial (including the components of personnel, production, accounting, engineering, marketing and entrepreneurial) capabilities. While this is indeed a strategic dimension of capabilities that firms acquire or develop to compete, the focus of this paper is on technological capabilities. Nevertheless, the technological aspects of management capabilities are embodied in personnel, techniques, routines, machinery, organizational and layout restructuring that can be captured in process technology, and product engineering, designing and marketing involving product technology (Rasiah 2010). However, because of the nature of garment manufacturing in LDCs where the value chains are driven by buyers abroad, firms generally do not relocate or develop significant levels of marketing capabilities at host locations.

Also, while acknowledging its powerful influence on synergizing national firms, we choose not to use technological spillovers in the paper as it is often non-pecuniary in nature and it falls outside market-based transactions (Scitovsky 1964; Rosenstein-Rodan 1984; Rasiah 1994). Given that a significant amount of knowledge spillover never gets appropriated by economic agents it may not be meaningful to attempt estimating them at all (Rasiah 2008). Hence, conforming to the evolutionary characteristics, this paper uses the concept of technological capabilities, which refer to 'tangible and intangible assets' firms acquire or develop to compete (Lall 1992). Given its estimation on the basis of embodied technologies, it allows the capture of capabilities firms possess and have at their disposal to carry out certain specified activity. The specific categories, phases and processes of technological change were analysed lucidly by Rosenberg (1976). Rosenberg and Frischtak (1985) defined technological capability as a process of accumulating technical knowledge or a process of organizational learning. Dahlman et al. (1987) emphasized the underlying concept of capability deepening as firms move from technology-using to innovation-driving production capabilities. The sequence of capabilities they developed - running from production capability through investment capability to innovation capability became the basis of the taxonomies of technological capabilities developed by Bell (1986) and Lall (1992).

Three categories of technology flows were grouped together by Bell (1986). Flow A consisted of capital goods and technological, engineering and management services. Flow B consisted of the skills and know-how to operate and maintain the newly established production 
technology. Flow $\mathrm{C}$ consisted of the knowledge and expertise to implement technical change, or the 'know-why'. In this framework, flow A led to an improvement in production capability, flow B contributed to technological capability at the basic and routine levels, and flow $\mathrm{C}$ enabled the firm to generate dynamic technical and organizational change.

The functional categorization of technological capabilities based on the tasks facing a manufacturing firm was subsequently outlined by Lall (1992). He divided the capabilities associated with the tasks into two groups: investment capabilities and production capabilities. These were further subdivided into three levels of capabilities: a basic level consisting of simple and experience-based capabilities; an intermediate level consisting of adaptive and duplicative but research-based capabilities; and an advanced level consisting of innovative and risky but also research-based activities.

Wei (1995) integrated Lall's functional categories with Bell's technology flow classification. He concluded, first, that not all technology flows generate technological capability, and second, that linkages with national supplier and other firms in a national economy are critical for enhancing capability. Rasiah (2010) drew on these contributions to focus on production capabilities only, establishing in the process a typology of capabilities based on the depth and trajectory of knowledge among firms. This framework allowed the measurement of three different types of embodied technological capability: human resources, process technology and product technology so as to facilitate the estimation of the overall technological capability (TC) of a firm.

\subsection{Ownership and exports}

Foreign firms tend to dominate export activities from LDCs because of their superior access to global markets. Many of these firms relocate low value added labor-intensive activities in countries that offer them location specific advantages to export. The prime motive of foreign firms relocating in Myanmar is to access the preferential quota privileges provided by the developed countries, though, wages and land costs are also lower than the rival sites in the rest of Southeast and East Asia (Rasiah 2009). This also fits into Dunning's (1995) eclectic paradigm of OLI where both ownership (market access) and location (host-site's quota privileges and low wages) conditions were instrumental in foreign firms relocating operations in Myanmar. The former obviously offers the potential for host-sites to appropriate export market synergies.

Foreign firms also generate export synergies in the domestic economy at host-sites either through subcontracting or demonstration effect (Caves 1974). Where the embedding environment is supportive national firms gradually grow to compete with firms in export markets. Indeed, Hirschman (1970) argued lucidly that export-orientation by multinationals offer the scale for the expansion of backward linkages in the host site. Hence, while the greater market access of foreign firms is likely to be reflected in higher export-intensities, national firms in especially countries with small domestic markets are also likely to participate in export markets. However, given the lack of financial resources and marketing capabilities in national firms, only some of them are likely to enjoy relatively high export-intensities. 
The inductive approach through the brainstorming session with officials of MGMA and pilot interviews with five firms show that ownership should be positively correlated with export intensities because of their superior access to global markets and technological support from their foreign plants. Hence, we hypothesize that foreign firms will show higher export intensities than national firms.

\subsection{Technological capabilities and exports}

Marx (1957) had argued that competition forces firms to replace old modes of technology with new ones, which Schumpeter (1934) referred to as the gales of creative destruction. Firms thus equip themselves with the minimum threshold of technological capabilities to compete in export markets. Whereas foreign firms relocate standardized capabilities from parent plants abroad (Vernon 1966), national firms either acquire or develop them in-house to compete in export markets. However, when the host-site involved is a LDC endowed with poor infrastructure, firms undertake adaptive engineering operations to reduce defects, improve quality and shorten delivery times (Rasiah 2011).

Also, purely on the basis of scale, exporting will generate a positive impact on firm-level technological capabilities (Smith 1776; Hirschman 1958, 1970). Lileeva and Trefter (2010) provided evidence from Canadian firms to show that exposure to export markets increased both innovation and labour productivity. However, the relative importance of export-intensities by ownership may differ especially with the specificity of the industry. If competitive multinationals are involved, their superior experience and tacit relationships in global markets will generally make firms enjoying majority foreign equity more export-intensive than national firms located in small domestic markets. Helleiner (1973) had argued that the decomposition of production into different stages actually helped raise not only investment and employment but also exports from host-sites in developing economies. This premise holds well with Myanmar as the relocation of multinational firms was targeted at export-oriented production. Hence, we hypothesize that technological capabilities will be positively correlated with export-intensities.

\subsection{Ownership and technological capabilities}

Garment manufacturing in Myanmar is undertaken by foreign subsidiaries and national firms equipped with original equipment manufacturing capabilities to carry out CMP operations. Because Myanmar integrated in global garment value chains in the 1990s when national firms were not equipped with significant technological capabilities, foreign firms are likely to dominate export sales from the country. Foreign firms internalize their production capabilities through the relocation of process and human resource capabilities at host sites to export from subsidiary locations. This fits into Dunning's (1995) eclectic paradigm of ownership, location and internalization (OLI) where both ownership (production technology and market access) and location (host-site) conditions were instrumental in foreign firms relocating operations in Myanmar. The former obviously offers the potential for host-sites to appropriate technological and export market synergies. With no serious competition from 
national firms and weak basic and high tech infrastructure, foreign firms tend to specialize in production-based technologies using human resource and process technology capabilities to meet quantitative fluctuations in orders and quick changes in designs.

Given the lack of supporting R\&D infrastructure in Myanmar, firms are unlikely to demonstrate technological capabilities beyond adaptive and quick turnaround capabilities to continuously lower production costs, replacement times, delivery times, and raise quality. Typically the large retail marts and brand holders undertake the promotion of brands (and sometimes designs), while foreign subsidiaries supply the OEM capabilities to the operators in Myanmar. Especially firms from East Asia either supply the technology and orders to their own subsidiaries in Myanmar or acquire them from national firms. Since external markets demand a certain threshold of technological capability only firms capable of delivering it participate in exporting. Foreign firms with superior endowments abroad tend to enjoy higher technological capabilities than national firms, though national firms will need some threshold of technological capabilities to compete in export markets. Hence, we hypothesize that foreign firms will enjoy higher technological capabilities than national firms.

\subsection{Control variables of age, wages and size}

While ownership, exports and technological capabilities are the explanatory variables used in the paper, it is also important to identify important control variables that past studies have established to be significant. Past works show that the relationship between age and exports is ambiguous. On the one hand, firms with more export experience might have higher export performance because their experience may offer them longer connection with the international supply chain. On the other hand, newer plants often export more because they can start with newer machinery and equipment, which can raise productivity and product quality (Ramstetter 1999; Jongwanich 2010; Rasiah 2011). Interestingly, foreign firms in the sample show longer years of operation than national firms, which supports our interviews that modern garment manufacturing in Myanmar was started off by foreign firms. However, given the runaway nature of a number of foreign garment firms owing to the uncertainty associated with in-bond operations and market access quotas, age may not be a significant relationship with exports and technological once controlled for other variables.

Also, wages was used to control for labour market effects. In theory, skilled workers are paid higher wages so that they can raise productivity. Indeed, export markets require high quality and hence skilled workers often command a wage premium (Schank et al. 2007). However, firms producing low end garments and competing on the basis of price may actually prefer to hire low wage workers.

Firm size is often regarded by researchers as a critical variable in explaining export behavior and success (Aw et al. 2011). Industrial district (Marshall 1920; Piore, Sabel 1984; Rasiah 1994; Pyke, Sengenberger 1992) exponents argue that SMEs are better allocators and coordinators of resources and production owing to their flexibility and agility to enter and exit markets. Unlike the impersonal large firm, SMEs are considered to provide greater room for horizontal relationships that support trust and social capital. In addition, Audretsch (2002) and Acs and Audretsch (1988) produced evidence from the United States to argue that SMEs 
participate more in $\mathrm{R} \& \mathrm{D}$ activities than large firms. Unlike the dynamic methodology used to capture relationships by industrial district exponents, Audretsch (2002), Acs and Audresch (1988) and Rasiah (1994) used statistical evidence to argue over the allocative and flexibility advantages of small firms. However, given the specificity of low value added low margin operations involving export-oriented CMP garment manufacturing, scale is likely to play an important role to support exporting activities.

The primary focus of the paper is then to compare export-intensities and technological capabilities by ownership, and to examine the relationship between export-intensities and technological capabilities of garment firms in Myanmar controlling for age, wages and size. Higher export-intensities and technological capabilities in foreign firms offer the potential for knowledge spillovers to national firms, which will depend on the embedding support provided by meso organizations at the host-site.

\section{Data and methodology}

Consistent with evolutionary approaches (Nelson 2008), we carried out a brainstorming session with the MGMA officials and five pilot firms to understand the specificity of garment manufacturing operations in Myanmar before testing the relationships between the explanatory variables. Primary data was collected from garment firms in Myanmar using a structured sampling framework on the basis of ownership and size. The breakdown of the 72 firms that responded to our survey were 22 enjoying foreign equity of $50 \%$ and more and 50 firms with less than $50 \%$ or zero foreign equity. The MGMA assisted with the collection of the data. Unless otherwise stated, the data reported is for July 31, 2010.

The methodology used in this exercise was adapted from Rasiah (2011) with the aim of contributing to the existing literature on understanding the relationship between ownership, technological capabilities and export-orientation in low value added low margin operations located in a LDC site that offers preferential access to developed countries' markets.

\subsection{Specification of variables}

Two sets of variables are specified in this section. The explanatory variables were specified first followed by the control variables.

\section{Export Intensity}

Export intensity was measured as follows:

$$
\text { Export Intensity }=X_{i} / Y_{i} \text {, }
$$

where $\mathrm{X}$ and $\mathrm{Y}$ refer to exports and gross output respectively of firm $i$ in 2010 .

\section{Technological Capabilities}

Drawing on Rasiah (2011), technological intensity (TI) was measured by incorporating the three proxies HR, process technology (PT), and adaptive engineering (AE) intensities. These three capabilities constitute the estimation of technological intensity used in the paper. 
S32 R. Rasiah, M. M. Myint. Ownership, technological capabilities and exports of garment firms...

\section{Human Resource}

HR intensity is expected to have a positive relationship with export intensities. HR intensities were measured as follows:

$$
\mathrm{HR}=1 / 3\left[\mathrm{TM}_{i}, \mathrm{TE}_{i}, \mathrm{CHR}_{i}\right],
$$

where TM, TE, and CHR refer to training mode, training expenditure in payroll, and the number of cutting-edge HR practices used by the firm i, respectively. TM was measured by assigning the value of 4 if the firm had a separate training centre, 3 if the firm had a training department, 2 if the firm had staff with training responsibilities, and 1 if the firm sent employees for training outside. TE was estimated by dividing training expenditure with payroll of firm i. CHR was measured by a score of 1 for each of the cutting-edge HR practices ticked by firm I-teamwork, informal work-related contact between managers and employees, multi-skilling and cross-department skilling, employee participation in small group innovation activities, continual learning, and clear guidelines for promotion. The proxies were then normalized as follows:

$$
\text { Normalization Score }=\left(X_{i}-X_{\min }\right) /\left(X_{\max }-X_{\min }\right) \text {, }
$$

where $X_{i}, X_{\min }$, and $X_{\max }$ refer to the $i$ th, minimum, and maximum values of the proxy $X$.

\section{Process Technology}

Process technology (PT) intensity refers to capabilities related to machinery and equipment, processes and quality control techniques used. PT was measured as follows:

$$
\mathrm{PT}=1 / 2\left[\mathrm{QM}_{i}, \mathrm{QIC}_{i}\right]
$$

where QM and QIC refer to the quality of machinery and equipment, and cutting-edge quality, and inventory control systems, respectively. Likert scale scores ranging from 1 to 7 (world class to dated) were used to measure QM, and QIC was estimated by adding a value of one to the use of each cutting-edge quality and inventory control practice reported by the firms-materials requirement planning (MRP), materials resource planning (MRP1), statistical process control (SPC), quality control circles (QCC), emphasis on reducing defects, and emphasis on shortening throughput times. QM and QIC were then normalized using the same formula used in the computation of HR (1).

\section{Adaptive Capabilities}

The pilot survey showed that manufacturing firms in Myanmar were only engaged in minor process and product adaptations and organizational restructuring using engineering capabilities. None of the firms reported any expenditure on $R \& D, R \& D$ personnel in their payroll or any outsourced $R \& D$ contract. Hence, adaptive capabilities (AC) rather than R\&D is used in the paper to denote a stage before R\&D. Higher levels of AE intensity are expected to be correlated with higher levels of export-intensity, and was estimated as follows:

$$
\mathrm{AC}=1 / 2\left[\mathrm{AME}_{\mathrm{i}}, \mathrm{AP}_{\mathrm{i}}\right] \text {, }
$$

where AME and AP refer to Likert scale (1-7) measure of intensity of adaptation of machinery and equipment, and adaptation to products of firm $i$. The values were normalized so that AC 
obtains a possible minimum value of 0 and maximum possible value 1 for export-intensity, and 3 for technological capability.

Technological capability (TC) was then measured by using the formula:

$$
\mathrm{TC}_{i}=\mathrm{HR}_{i}+\mathrm{PT}_{i}+\mathrm{AC}_{i}
$$

Given no a priori qualifications on the greater significance of any one of the three technological capabilities, and because their significance is likely to vary with the location of firms in the overall technological trajectories (Rasiah 2011), no attempt was made to weight technological capabilities.

\section{Ownership}

Ownership is the last explanatory variable examined in the paper and was estimated as follows: $\mathrm{FO}=1$ if foreign equity is $50 \%$ or more; $\mathrm{FO}=0$ otherwise.

\section{Control Variables}

The variables of Age, size and wages were used to examine the influence of instrumental variables.

Age

Because the values of the dependent variables of export-intensity vary between 0 and 1 , and technological capability vary between a minimum possible value of 0 and a maximum possible value of 3 , age was estimated as follows:

$$
A=\operatorname{Ln} \text { (years of export experience). }
$$

\section{Wage}

Wages was estimated by taking the total amount of salaries per month and dividing it by the number of workers. Monthly wages were then converted from the national currency of Kyat to US\$ with the appropriate exchange rate. ${ }^{4}$ Because the values of the dependent variables of export-intensity vary between 0 and 1 , and technological capability vary between a minimum possible value of 0 and a maximum possible value of 3 , wage in the regressions was estimated as follows:

$$
W=\operatorname{Ln} \text { (total monthly salaries/total numbers of employees). }
$$

\section{Size}

The values of the dependent variables of export-intensity vary between 0 and 1 , and technological capability vary between a minimum possible value of 0 and a maximum possible value of 3 , and hence, firm size was estimated as follows:

$$
\text { Firm size, } \mathrm{S}=\mathrm{Ln} \text { (total number of employees). }
$$

\footnotetext{
$4 \quad$ We used the average exchange rate of K 1200 to one US\$ of the year 2007.
} 
S34 R. Rasiah, M. M. Myint. Ownership, technological capabilities and exports of garment firms...

\subsection{Statistical exercise}

Two sets of statistical exercises were carried out to determine the importance of foreign ownership in Myanmar's garment manufacturing sector. The first uses descriptive statistics to examine statistical differences. The second uses regressions to test the hypotheses of the paper by controlling for other influences. The first and second hypotheses can be expressed statistically as follows:

$$
X / Y=\mathrm{F}(\mathrm{TI}, \mathrm{FO}, \mathrm{W}, \mathrm{S}, \mathrm{A}) .
$$

The third hypotheses of the paper can be expressed as follows:

$$
\mathrm{TI}=\mathrm{F}(\mathrm{FO}, \mathrm{W}, \mathrm{S}, \mathrm{A}) \text {. }
$$

A correlation test was carried out between the independent variables to remove multicolinearity problems. The variables of TI, FO, W and S show excessive correlations so that the use of any two of them on the right hand side of the equations produced biased coefficients (Table 1). Hence, four regressions were carried out to estimate the coefficients of independent variables against the dependent variable of $\mathrm{X} / \mathrm{Y}$ and three regressions were undertaken to estimate the coefficients of the independent variables against the dependent variable of TI.

Table 1. Correlation coefficient matrix, independent variables, Garment firms, Myanmar, 2010

\begin{tabular}{cccccc}
\hline & A & FO & S & TI & W \\
\hline A & 1.000 & 0.214 & 0.298 & 0.131 & 0.252 \\
FO & 0.214 & 1.000 & $0.490^{*}$ & $0.524^{*}$ & $0.643^{*}$ \\
S & 0.298 & $0.490^{*}$ & 1.000 & $0.521^{*}$ & $0.303^{*}$ \\
TI & 0.131 & $0.524^{*}$ & $0.521^{*}$ & 1.000 & $0.345^{*}$ \\
W & 0.252 & $0.643^{*}$ & $0.303^{*}$ & $0.345^{*}$ & 1.000 \\
\hline
\end{tabular}

Note: ${ }^{\star}$ Excessive correlation.

Source: Computed from Authors' Survey (2010)

OLS was preferred when the dependent variable used was X/Y. Tobit regressions were preferred when the values of the dependent variable, TI, as it is censored on the left (minimum possible value of 0 ) and on the right (maximum possible value of 3) (Greene 2011). The following equations were specified:

$$
\begin{aligned}
& \text { OLS: } X / Y=\alpha+\beta_{1} \mathrm{FO}+\beta_{2} A+\mu ; \\
& \text { OLS: } X / Y=\alpha+\beta_{1} \mathrm{TI}+\beta_{2} A+\mu ; \\
& \text { OLS: } X / Y=\alpha+\beta_{1} W+\beta_{2} A+\mu ; \\
& \text { OLS: } X / Y=\alpha+\beta_{1} S+\beta_{2} A+\mu ; \\
& \text { Tobit: } T C=\alpha+\beta_{1} \mathrm{FO}+\beta_{2} A+\mu ;
\end{aligned}
$$




$$
\begin{aligned}
& \text { Tobit: } T C=\alpha+\beta_{1} W+\beta_{2} A+\mu ; \\
& \text { Tobit: } T C=\alpha+\beta_{1} S+\beta_{2} A+\mu .
\end{aligned}
$$

We did not undertake separate ownership-based regressions because of the small number of foreign firms at twenty two in the sample. There was only a population of 23 foreign firms in Myanmar in 2010.

\subsection{Statistical data}

The descriptive statistics of the results are presented in Tables 2 and 3. Table 2 presents data of all members of MGMA. Table 3 presents data of sample generated from the survey. Based on establishment numbers, the industry is dominated by national firms, which accounted for 107 of the garment firms registered with the MGMA in 2010 (Table 2). Foreign firms (including joint-ventures) accounted for 23 of the member firms. However, the mean size of foreign firms (742 workers) was much larger than national firms (266 workers). Foreign firms (794 machines) also had a much higher mean number of sewing machines than national firms (150 machines). National firms (0.56) had a slightly higher mean sewing machine per worker ratio than foreign firms (0.50).

Table 2. Characteristics of firms and capabilities, Garment Industry, Myanmar, 2010

\begin{tabular}{lccc}
\hline \multicolumn{1}{c}{ Particulars } & Foreign & National & Total \\
\hline Number of firms & 23 & 107 & 130 \\
Number of workers & 14170 & 29550 & 43720 \\
Number of sewing machines & 7140 & 16649 & 23789 \\
Workers per firm (Numbers) & 742 & 266 & 336 \\
Sewing machines per firm & 794 & 150 & 183 \\
Sewing machines per worker & 0.50 & 0.56 & 0.54 \\
\hline
\end{tabular}

Source: MGMA (2010)

The sampled firms show that foreign firms are more export-oriented with minimum and maximum export intensities ranging from $60 \%$ to $100 \%$ while that of national firms ranged from $20 \%$ to $100 \%$ (Table 3 ). Nevertheless, the data collected shows that some national firms raised their export share from $93 \%$ in 2007 to 100\% in 2010. Foreign firms enjoyed higher minimum and maximum TC than national firms. This was the same in all the three components of technological capabilities. Interviews show that foreign firms use superior process technology drawn from their parent plants than national firms.

Foreign firms enjoyed much higher minimum and maximum employment size than national firms. Foreign firms also enjoyed higher minimum and maximum values of wages and export experience than national firms. The mean monthly wage paid by foreign firms (US\$ 47.51) was higher than that of national firms (US\$33.40). Against a minimum wage 
S36 R. Rasiah, M. M. Myint. Ownership, technological capabilities and exports of garment firms...

of US\$ 65 in Cambodia in 2009, ${ }^{5}$ isolation from the United States and the lack of minimum wage legislation in Myanmar has kept minimum wages at US\$ 31.65 by foreign firms and US\$ 18.22 by national firms.

Table 3. Descriptive statistics, Garment firms, Myanmar, 2010

\begin{tabular}{lcccccc}
\hline & \multicolumn{2}{c}{ Minimum } & \multicolumn{2}{c}{ Maximum } & \multicolumn{2}{c}{ Standard Deviation } \\
\cline { 2 - 7 } & Foreign & National & Foreign & National & Foreign & National \\
\hline X/Y & 0.60 & 0.20 & 1.00 & 1.00 & 0.13 & 0.23 \\
TC & 0.99 & 0.73 & 2.44 & 2.04 & 0.35 & 0.37 \\
PT & 0.42 & 0.17 & 0.83 & 0.83 & 0.14 & 0.15 \\
AC & 0.00 & 0.00 & 1.00 & 0.63 & 0.23 & 0.21 \\
HR & 0.33 & 0.19 & 1.00 & 0.57 & 0.18 & 0.17 \\
AGE & 3.00 & 7.00 & 20.00 & 15.00 & 3.39 & 2.70 \\
A & 1.95 & 1.10 & 3.00 & 2.71 & 0.28 & 0.32 \\
WAGE (US\$)* & 31.65 & 18.22 & 63.25 & 45.00 & 9.35 & 5.83 \\
W & 3.46 & 2.90 & 4.15 & 3.81 & 0.21 & 0.19 \\
Size & 125 & 100 & 2800 & 1800 & 688.69 & 368.01 \\
S & 4.83 & 4.61 & 7.94 & 7.50 & 0.73 & 0.65 \\
\hline
\end{tabular}

Note: ${ }^{\star}$ Mean monthly wages of individual firms used in the estimation.

Source: Computed from Authors' Survey (2010)

\section{Statistical analysis}

The results of the two exercises are analyzed in this section. Statistical differences using the Levene's two-tail t-tests are examined in the first sub-section while multiple regressions results are analyzed in the second subsequent sub-section.

\subsection{Statistical differences}

The Levene's two-tail ' $t$ ' test of means shows that foreign firms enjoyed higher export intensities and technological capabilities than national firms (Table 4). Also, some national firms have achieved complete export-orientation and strong technological capabilities. Nevertheless, some national firms enjoyed higher technological capabilities (including the components of $\mathrm{HR}, \mathrm{PT}$ and $\mathrm{AC}$ ) than some foreign firms as the maximum values of the former were higher than the minimum values of the latter. A few national firms have acquired and developed technological capabilities comparable to foreign firms to compete with them in export markets.

Foreign firms also enjoyed higher wage and employment size, and the results are statistically significant. Given the small demand in the domestic market, it is understandable

5 Data supplied by Chettra on 25 June 2011 from the National Planning Ministry, Phnom Penh. 
that the superior production and market access capability of foreign firms accessed from their parent plants abroad have ensured that these firms show higher export intensities and technological capabilities than national firms. With higher capital endowments and larger market access foreign firms also were able to pay higher wages and employ more workers than national firms.

Table 4. Two tailed t-tests of critical variables, Garment firms, Myanmar, 2010

\begin{tabular}{|c|c|c|c|c|}
\hline & \multicolumn{2}{|c|}{ Mean } & \multirow{2}{*}{ Mean difference } & \multirow{2}{*}{$\mathrm{t}$} \\
\hline & Foreign & National & & \\
\hline X/Y@ & 0.949 & 0.566 & 0.383 & $7.304^{*}$ \\
\hline TC\# & 1.731 & 1.263 & 0.468 & $5.005^{*}$ \\
\hline PT\# & 0.674 & 0.467 & 0.208 & $5.825^{*}$ \\
\hline AC\# & 0.401 & 0.225 & 0.184 & $3.157^{\star}$ \\
\hline HR\# & 0.648 & 0.571 & 0.076 & $1.717^{\star *}$ \\
\hline $\mathrm{W} \#$ & 3.842 & 3.492 & 0.350 & $6.816^{*}$ \\
\hline S@ & 6.786 & 5.973 & 0.813 & $4.703^{*}$ \\
\hline $\mathrm{A \#}$ & 2.405 & 2.262 & 0.143 & $1.936^{\star *}$ \\
\hline No of firms $(N)$ & 22 & 50 & & \\
\hline
\end{tabular}

Notes: @ - equal variances assumed as F-statistics was significant; \# - equal variances not assumed as F-statistics not significant; ${ }^{*}$ and ${ }^{* *}$ refer to statistical significance at $1 \%$ and $10 \%$ levels respectively.

Source: Computed from Authors' Survey (2010).

Overall, the analysis of statistical differences shows that foreign firms enjoy higher export-intensities, technological capabilities, employment size and wages than national firms, thereby suggesting that the former can potentially provide knowledge spillover to the latter. However, consistent with Hirschman's (1970) argument, this potential can only be realized if the host-government can create and strengthen the institutional support for its appropriation by national firms.

\subsection{Statistical analysis}

The OLS and Tobit regressions produced interesting results. The model fit (F-stat and log likelihood) was statistically significant for the interpretation of results (Table 5). All regressions also passed the Cooke-Wiesberg test for heteroskedasticity.

The relationship between foreign ownership and export-intensity is positive and highly significant ( $1 \%$ level) confirming the first hypothesis of the paper. The relationship between technological capability and export-intensity was also positive and highly significant (1\% level), confirming the second hypothesis of the paper. Size was also statistically significant confirming that larger firms are more export-oriented than smaller firms in Myanmar's garment manufacturing sector. The relationship between export-intensities and wages was 
S38 R. Rasiah, M. M. Myint. Ownership, technological capabilities and exports of garment firms...

also positive and strong (1\% level), showing that higher wages has been instrumental in supporting higher export-intensities.

The relationship between foreign ownership and technological capabilities is positive and highly significant (1\% level), confirming the third hypothesis of the paper. Size and wages were also positively correlated with technological capabilities. Hence, larger firms show higher technological capabilities than smaller firms, and firms paying higher wages show higher technological capabilities than firms paying lower wages.

The influence of the instrumental variables show that size and higher wages have been important in supporting export competitiveness and technological capabilities in Myanmar's garment manufacturing industry. The evidence shows that even in a technology using industry such as garments and in LDC locations, higher wages (premium enjoyed by skilled workers) rather lower wages is the driver of competitiveness and technological capabilities. Scale has been important in garment manufacturing as specialization in just CMP activities requires large volume to enjoy aggregate profits because of the small margins. Foreign firms show the potential for offering strong economic and technological synergies to the domestic economy as they show higher export-intensities and technological capabilities than national firms.

Table 5. Export intensity and technological capability regressions, Garment firms, Myanmar, 2010

\begin{tabular}{|c|c|c|c|c|c|c|c|}
\hline & \multicolumn{4}{|c|}{ OLS: XY } & \multicolumn{3}{|c|}{ Tobit: TC } \\
\hline A & $\begin{array}{c}0.105 \\
(1.317)\end{array}$ & $\begin{array}{c}0.192 \\
(1.954)^{* * *}\end{array}$ & $\begin{array}{c}0.121 \\
(1.305)\end{array}$ & $\begin{array}{c}0.062 \\
(0.739)\end{array}$ & $\begin{array}{c}0.026 \\
(0.189)\end{array}$ & $\begin{array}{c}0.062 \\
(0.408)\end{array}$ & $\begin{array}{c}-0.036 \\
(-0.257)\end{array}$ \\
\hline $\mathrm{FO}$ & $\begin{array}{c}0.368 \\
(6.890)^{\star}\end{array}$ & & & & $\begin{array}{c}0.464 \\
(5.058)^{\star}\end{array}$ & & \\
\hline TC & & $\begin{array}{c}0.181 \\
(2.463)^{\star *}\end{array}$ & & & & & \\
\hline W & & & $\begin{array}{c}0.497 \\
(4.363)^{*}\end{array}$ & & & $\begin{array}{c}0.548 \\
(2.923)^{\star}\end{array}$ & \\
\hline S & & & & $\begin{array}{c}0.217 \\
(6.421)^{*}\end{array}$ & & & $\begin{array}{c}0.285 \\
(4.355)^{\star}\end{array}$ \\
\hline $\mathrm{C}$ & $\begin{array}{c}0.328 \\
(1.793)^{* * *}\end{array}$ & $\begin{array}{c}-0.012 \\
(1.954)^{\star \star}\end{array}$ & $\begin{array}{c}-1.385 \\
(-3.355)^{\star}\end{array}$ & $\begin{array}{c}-0.812 \\
(-3.367)^{\star}\end{array}$ & $\begin{array}{c}1.204 \\
(3.824)^{\star}\end{array}$ & $\begin{array}{c}-0.710 \\
(-1.046)\end{array}$ & $\begin{array}{c}-0.283 \\
(-0.700)\end{array}$ \\
\hline $\mathrm{R} 2$ & 0.446 & 0.141 & 0.268 & 0.415 & & & \\
\hline F-stat & $27.824^{*}$ & $5.669^{*}$ & $12.609^{*}$ & $24.487^{\star}$ & & & \\
\hline LL & & & & & $-26.669^{*}$ & $-33.576^{\star}$ & $-26.803^{\star}$ \\
\hline
\end{tabular}

Note: Figures in parentheses refer to $\mathrm{t}(\mathrm{OLS})$ and $\mathrm{z}$ (Tobit) statistics; ${ }^{*},{ }^{* *}$ and ${ }^{* * *}$ refer to statistical significance at $1 \%, 5 \%$ and $10 \%$ respectively.

Source: Computed from Authors Survey (2010)

Overall, all three hypotheses are supported by the evidence from garment firms in Myanmar. Also, foreign firms demonstrated significantly higher export-intensities and technological capabilities than national firms demonstrating that they can potentially offer positive knowledge spillovers for its appropriation by national firms. The fact that a few national firms 
have higher export intensities and technological capabilities than some foreign firms all the more reinforces the view that positive knowledge spillovers are possible. Large size and higher wages support higher export-intensities and technological capabilities.

\section{Conclusions}

It can be seen that the garment industry, which began to contract initially from economic sanctions imposed by the United States in 2003, has continued to operate in Myanmar. Opportunities from market openings elsewhere has continued to drive export growth from the industry, albeit slowly. It is under such conditions that differences in export intensities and technological capabilities between foreign and national firms were examined in this paper. Interestingly, even under such a depressed political and infrastructure environment, foreign firms generally enjoyed higher export and technological capabilities than national firms. Whereas foreign firms enjoy superior mean technological capabilities (and the components of HR, process and adaptive capabilities) than national firms, a few national firms that show strong export intensities and technological capabilities demonstrate the potential that knowledge spillovers can be realized by national firms if the government of Myanmar strengthens the institutions and related supporting meso organizations. These findings strengthen the evolutionary argument that empirical specificity is important to capture the real drivers of technical change at host sites, which is also worth being investigated in LDCs (Nelson 2008).

Technological capabilities and export-intensities are highly and positively correlated, which is in line with the famous Smith (1776) and Young (1928) dictum, that causation between the two goes both ways. This along with the statistically highly significant higher export-intensities enjoyed by foreign firms over national firms suggests that there are export and technological synergies that national firms can potentially appropriate from the demonstration effect shown by foreign firms in Myanmar.

With garment firms in Myanmar sourcing a quarter of their inputs domestically in 2004, and technological upgrading occurring in large export-oriented national firms, the evidence suggests that the country may be able to support a more viable industry than the Maquiladoras in Latin America provided the government pursues institutional strengthening. Hence, it will help the government of Myanmar to take steps to make the country an attraction again for foreign firms by bringing back greater stability and security. There should also be efforts to assist national firms with financial, marketing and technological support to stimulate further their participation in export markets. Given that small national firms are more vulnerable to external shocks than foreign and large national firms as evidenced from the many shutdowns following the American economic sanctions in 2003, the government must offer strong support through the creation and strengthening of meso organizations to assist them. National firms and Myanmar workers will also have much to benefit if the democratization that is taking place since the second half of 2011 leads to the lifting of sanctions by the United States, the government strengthens the basic infrastructure and training organizations, and introduces in the country labour covenants of the International Labor Organization. 
S40 R. Rasiah, M. M. Myint. Ownership, technological capabilities and exports of garment firms...

\section{Acknowledgement}

We wish to thank the editor and three anonymous referees for their constructive comments. The usual disclaimer applies.

\section{References}

Acs, Z. J.; Audretsch, D. B. 1988. Innovation and small firms. Cambridge, MA: MIT Press.

Audretsch, D. B. 2002. The dynamic role of small firms: evidence from the US, Small Business Economics 18(1-3): 13-40. http://dx.doi.org/10.1023/A:1015105222884

Aw, B. Y.; Roberts, M.; Yi, X. 2011. R\&D investment, exporting and productivity dynamics, American Economic Review 101(4): 1312-1344. http://dx.doi.org/10.1257/aer.101.4.1312

Bailey, P.; Parisotto, A.; Renshaw, G. 1993. Multinationals and employment. Geneva: International Labour Office.

Barrientos, S. 2008. Contract labour: the 'Achilles Heel' of corporate codes in commercial value chains, Development and Change 39(6): 977-990. http://dx.doi.org/10.1111/j.1467-7660.2008.00524.x

Bell, R. M. 1986. The acquisition of imported technology for industrial development: problems of strategy and management in the Arab region. UN Economic Commission for Western Asia, Baghdad.

Caves, R. 1974. Multinational firms, competition and productivity in host-country markets, Economica 41(162): 176-93. http://dx.doi.org/10.2307/2553765

Dahlman, C. J.; Ross-Larson, B.; Westphal, L. E. 1987. Managing technical development: lessons from the newly industrializing countries, World Development 15: 759-75. http://dx.doi.org/10.1016/0305-750X(87)90058-1

Dunning, J. 1995. Reappraising the eclectic paradigm in an age of alliance capitalism, Journal of International Business Studies 26(3): 461-491. http://dx.doi.org/10.1057/palgrave.jibs.8490183

Fatemi, K. 1990. The maquiladora industry: economic solution or problem? New York: Praeger Publishers.

Freeman, C. 1987. Technology policy and economic performance: lessons from Japan. London: Pinter Publishers.

Freeman, C. 1989. New technology and catching-up, European Journal of Development Research 1(1): 85-99. http://dx.doi.org/10.1080/09578818908426503

Gereffi, G. 1994. The organization of buyer-driven global commodity chains: how US retailers shape overseas production networks, in Gereffi, G.; Korzeniewicz, M. (Eds.). Commodity chains and global capitalism. Westport: Praeger, 95-122.

Greene, W. 2011. Econometric analysis. $7^{\text {th }}$ edition, New Jersey: Prentice Hall.

Helleiner, G. 1973. Manufactured exports from less-developed countries and multinational firms, Economic Journal 83(329): 21-47. http://dx.doi.org/10.2307/2231098

Hirschman, A. O. 1958. The strategy of economic development. New Haven: Yale University Press.

Hirschman, A. O. 1970. Exit, voice and loyalty: responses to decline in firms organizations and states. Cambridge: Harvard University Press.

Jongwanich, J. 2010. Determinants of export performance in East and Southeast Asia, World Economy 33(1): 20-41. http://dx.doi.org/10.1111/j.1467-9701.2009.01184.x

Kudo, T. 2005. The impact of United States sanctions on the Myanmar garment industry. Institute of Developing Economies (IDE), Tokyo, Discussion Paper No. 42.

Lall, S. 1992. Technological Capabilities and Industrialization, World Development 20(2): 165-86. http://dx.doi.org/10.1016/0305-750X(92)90097-F 
Lall, S. 1999. Competing with labour: skills and competitiveness in developing countries. Issues in development discussion Paper No. 31, International Labor Organization, Geneva.

Lileeva, A.; Trefter, D. 2010. Improved access to foreign markets raises plant-level productivity for some plants, Quarterly Journal of Economics 125(3): 1051-1099. http://dx.doi.org/10.1162/qjec.2010.125.3.1051

Lundvall, B. Å. 1992. Public policy in the learning society, in National Innovation Systems: towards a theory of innovation and interactive learning. London: Pinter Publishers.

Malerba, F. 2005. Sectoral systems: how and why innovation differs across sectors, in Fagerberg, J.; Mowery, D. C.; Nelson, R. R. (Eds.). The Oxford Handbook of Innovation, Oxford: Oxford University Press, 380-406.

Marshall, A. 1920. Principles of economics. London: Macmillan.

Marx, K. 1957. Capital, Vol. 2. Moscow: Progress Publisher.

MGMA 2010. Unpublished data. Myanmar Garment Manufacturing Association, Yangon.

Myint, M. M. 2011. Export performance, labour productivity and institutional environment of Myanmar garment manufacturing: PhD Thesis, Faculty of Economics and Administration, University of Malaya, Kuala Lumpur.

Myint, M. M.; Rasiah, R. 2012. Foreign capital and garment export from Myanmar: implications for the labour process, Institutions and Economies 4(3): 151-172.

Narula, R.; Dunning, J. 2010. Multinational enterprises, development and globalization: some clarifications and a research agenda, Oxford Development Studies 38(3): 263-287.

http://dx.doi.org/10.1080/13600818.2010.505684

Nelson, R. R.; Winter, S. G. 1982. An evolutionary theory of economic change. Cambridge: Harvard University Press. http://dx.doi.org/10.1080/13600810701848037

Nelson, R. R. 2008. Economic development from the perspective of evolutionary economic theory, Oxford Development Studies 36(1): 9-21.

Piore, M.; Sabel, C. 1984. The second industrial divide: possibilities for prosperity. New York: Basic Books.

Pyke, F.; Sengenberger, W. 1992. Industrial districts and inter-firm cooperation in Italy, Geneva: International Institute for Labour Studies.

Ramstetter, E. D. 1999. Trade propensities and foreign ownership shares in Indonesian manufacturing, Bulletin of Indonesian Economic Studies 35(2): 43-66. http://dx.doi.org/10.1080/00074919912331337587

Rasiah, R. 1994. Flexible production systems and local machine tool subcontracting: electronics transnational in Malaysia, Cambridge Journal of Economics 18(3): 279-298.

Rasiah, R. 2008. Ownership, institutions and technological intensities: automotive and electronics firms in East and Southeast Asia, in Eatwell, J.; Arestis, P. (Eds.). Issues in finance and industry: essays in honour of Ajit Singh. London: Pelgrave Macmillan.

Rasiah, R. 2009. Can garment exports from cambodia, laos and burma be sustained?, Journal of Contemporary Asia 39(4): 619-637. http://dx.doi.org/10.1080/00472330903076917

Rasiah, R. 2010. Are electronics firms in Malaysia catching up in the technology ladder?, Journal of Asia Pacific Economy 15(3): 301-319. http://dx.doi.org/10.1080/13547860.2010.494910

Rasiah, R. 2011. Ownership, R\&D and export intensities of automotive parts firms in East Asia, Asia Pacific Business Review 17(2): 143-160. http://dx.doi.org/10.1080/13602381.2011.533505

Rasiah, R.; Ofreneo, R. 2009. The dynamics of textile and garment manufacturing in Asia, Journal of Contemporary Asia 39(4): 501-511.

Rosernberg, N. 1976. Perspectives on technology. Cambridge: Cambridge University Press. http://dx.doi.org/10.1080/00472330903076727 
S42 R. Rasiah, M. M. Myint. Ownership, technological capabilities and exports of garment firms...

Rosenberg, N.; Frischtak, C. (Eds.). 1985. International technology transfer: concepts, measures, and comparisons. New York: Praeger. http://dx.doi.org/10.1017/CBO9780511561313

Rosenstein-Rodan, P. N. 1984. Natura facit saltum: analysis of the disequilibrium growth process, in Meier, G. M.; Seers, D. (Eds.). Pioneers in Development. New York: Oxford University Press.

Schank, T.; Schnabel, C.; Wagner, J. 2007. Do exporters really pay higher wages? First evidence from German linked employer data, Journal of International Economics 72 (1): 52-74. http://dx.doi.org/10.1016/j.jinteco.2006.08.004

Schumpeter, J. 1934. The theory of economic development: an inquiry into profits, capital, credit, interest, and the business cycle. Cambridge: Harvard University Press.

Scitovsky, T. 1964. Papers on welfare and growth. London: Allen \& Unwin.

Singleton, J. 1997. The world textile industry, competitive advantage in world industry. London: Routledge. Smith, A. 1776. The wealth of the nations. London: Strahan and Cadell.

Sturgeon, T.; Gereffi, G. 2009. Measuring success in the global economy: international trade, industrial upgrading, and business function outsourcing in global value chains, Transnational Corporations 18(2): 1-35.

Teece, D. T. 2009. Dynamic capabilities and strategic management: organizing for innovation and growth. New York: Oxford University Press.

Vernon, R. 1966. International investment and international trade in the product cycle, Quarterly Journal of Economics 80(2): 190-207. http://dx.doi.org/10.2307/1880689

Wei, L. 1995. International technology transfer and development of technological capabilities: a theoretical framework, Journal of Technology in Society 17(1): 103-120. http://dx.doi.org/10.1016/0160-791X(94)00028-C

Wikipedia 2012. Innovation [online], [cited 28 February 2012] Available from Internet: http://en.wikipedia.org/wiki/Innovation.

WTO. 2012. International trade statistics. Geneva: World Trade Organization (WTO).

Young, A. 1928. Increasing returns and economic progress, Economic Journal 38(152): 527-542. http://dx.doi.org/10.2307/2224097

Rajah RASIAH obtained his Doctorate in Economics from Cambridge University in 1992. He currently holds the post of Professor of Technology and Innovation Policy at University of Malaya, and his research focus is on the economics of technological change and technology policy.

Myo Myo MYINT obtained her Doctorate from University of Malaya in 2012. She is currently employed by the Friedrich Ebert Stiftung in Yangon. Her current research focus is on the development of the garment industry in Myanmar. 